\title{
Intensification of Dryland Cropping Systems for Bio-feedstock Production: Energy Analysis of Camelina
}

\section{Authors: Reza Keshavarz-Afshar \& Chengci Chen}

The final publication is available at Springer via http://dx.doi.org/10.1007/s12155-015-9644-8. This is a postprint of an article that originally appeared in BioEnergy Research in December 2015.

Keshavarz-Afshar, Reza, and Chengci Chen. "Intensification of Dryland Cropping Systems for Bio-feedstock Production: Energy Analysis of Camelina." BioEnergy Research 8, no. 4 (December 2015): 1877-1884. DOI: 10.1007/s12155-015-9644-8.

Made available through Montana State University's ScholarWorks scholarworks. montana.edu 


\section{Energy Analysis of Camelina}

3

4 Reza Keshavarz-Afshar and Chengci Chen*

6 Central Agricultural Research Center, Montana State University, Moccasin MT 59462, USA.

7

$8 *$ Corresponding author

9 Email: cchen@montana.edu;

10 Phone: 406-423-5421

11 Fax: 406-423-5422

12

13 
Intensification of Dryland Cropping Systems for Bio-feedstock Production:

Energy Analysis of Camelina

\section{Abstract}

17 Camelina sativa, as a bioenergy and bio-product feedstock, may be grown as a rotation crop in the wheat-based cropping system to increase land use efficiency in the Northern Great Plains

19 (NGP). In this study, we evaluated the energy balance of the camelina-winter wheat (CAM-WW)

20

21

22

23

24 compared with traditional fallow-winter wheat (FAL-WW) and barley-winter wheat (BAR-WW) cropping systems from 2008 to 2011 in Central Montana. Results indicated that 52 and 57\% more energy input was invested in CAM-WW and BAR-WW compared to FAL-WW system (9182 $\mathrm{MJ} \mathrm{ha}^{-1}$ ), respectively. In all rotations, nitrogen fertilizer was the most energy consuming input and accounted for 76, 68 and $71 \%$ of the total energy used in wheat, barley and camelina production, respectively. Averaged over three years, CAM-WW and BAR-WW systems yielded 34 and 29\% greater gross energy output compared with FAL-WW. The CAM-WW and BARWW also outperformed FAL-WW by 30 and $6 \%$ in terms of net energy output. No significant differences in energy efficiency were between the FAL-WW and CAM-WW systems. Taking into account the greater net energy as well as similar values of energy use efficiency, CAM-WW system apparently performed better in than the traditional FAL-WW system in this dryland farming system. There is a good potential to improve the energy efficiency of the CAM-WW cropping system (by more than 26\%) through refinement of agronomic practices, mainly nitrogen fertilization and herbicide application, which can further enhance the sustainability of camelina feedstock production. 
Keywords: Camelina, Cropping system, Energy input, Energy output, Energy efficiency,

37 Sustainability

Abbreviation: CAM-WW, Camelina-Winter Wheat; BAR-WW, Barley-Winter Wheat; FALWW, Fallow-Winter Wheat; NGP, Northern Great Plains.

\section{Introduction}

43 Camelina (Camelina sativa L. Crantz) is an annual oilseed crop belonging to the Brassicaceae 44 family [10]. Oil of this crop has been recognized as an outstanding feedstock for bioenergy purposes and recent studies have confirmed its superiority as a biodiesel and aviation fuel [10, $14,32]$. In the recent years, extensive efforts have been made to characterize camelina's

7 agronomic potential for the western and northern of the U.S. Great Plains and Canada [10, 11, 20]. Results of these studies confirmed that camelina can suitably fit with the environmental conditions and boundaries of the Northern Great Plains, thus, has potential to fill the fallow period of the wheat-based cropping systems to increase land use efficiency [6, 20]. Chen at al.

51 [6] reported that total biomass and grain yield are greater in camelina-wheat annual cropping 52 system than that in traditional fallow-wheat systems of Central Montana. Nevertheless, the 53 sustainability of camelina-wheat (Triticum aestivum L.) rotation (CAM-WW) compared to 54 traditional fallow-wheat (FAL-WW) system needs to be investigated. Effective use of non55 renewable energy sources is considered as a major component of sustainability in the agricultural 56 activity, especially bio-feedstock productions, thus; energy analysis is one useful indicator of 57 environmental and long-term sustainability of the cropping systems [2, 24]. Moreover, energy 58 analysis provides opportunities toward optimization of non-renewable energy consumption, 59 thereby contributing positively to reducing greenhouse gas emissions and to enhancing the long60 term environmental sustainability of the cropping systems [4, 27]. 
61 There were continuous debates on energy use efficiency or net energy gain for bioenergy

62 production of grain and biomass. Energy analysis of predominant bioenergy feedstocks such as

63 corn (Zea mays L.) [15, 23, 26], soybean (Glycine max L. Merr.) [9, 19, 26] and rapeseed

64 (Brassica napus L.) $[22,29,31]$ has been extensively investigated. Energy from biomass crops

65 (second generation feedstock) such as cardoon (Cynara cardunculus L.) giant reed (Arundo

66 donax L.), and Miscanthus spp. also has received sufficient attention from researchers [3, 7, 16].

67 It has been argued that suitable bio energy crops must yield significantly more energy that that

68 used in their production process (Lewandowski and Schmidt, 2006). Despite the great potential

69 of camelina for production of a climate friendly biofuel feedstock, the energy efficiency or

70 energy balance in this crop is not well documented yet.

71 Individual crops vary in their energy input and output; crop rotation, therefore, can impact

72 energetics of entire cropping systems. Zentner et al. [33] reported that non-renewable energy

73 consumption for the entire cropping systems was differed significantly with crop rotations in the

74 Canadian Prairies. Since nitrogen fertilizer is the most energy demanding input in most cropping

75 systems [12, 21], Zentner et al. [33] reported that the inclusion of pulse crops such as peas

76 (Pisum sativum L.) into the cropping systems can significantly reduce total energy input to the

77 systems due to their role in minimizing external nitrogen input. Burgess et al. [5] evaluated the

78 energy balance of 14 paired pulse -wheat and wheat-wheat crop sequences in Montana. They

79 concluded that diversification of the cropping systems in Montana with pulse crops will have

80 positive impacts on energy balance of the system.

81 In order to make camelina a viable bioenergy crop and to be able to produce the feedstock

82 efficiently and sustainably, the energetic performance of this crop should be evaluated. In the

83 present study, energy balance indicators, including energy efficiency and net energy, were used 
84 to evaluate energy performance of CAM-WW and barley (Hordeum vulgare L.)-wheat (BAR-

85 WW) rotations compared with traditional FAL-WW cropping system in a dryland environment

86 of the NGP. Potentials to improve the energy efficiency of these rotations through optimization

87 of the agronomic practices are also discussed.

\section{Materials and methods}

\section{Site description and experimental details}

91 The study was conducted at the Central Agricultural Research Center $\left(47^{0} 03^{\prime} \mathrm{N}, 109^{0} 57^{\prime} \mathrm{W}\right.$;

$921400 \mathrm{~m}$ elevation) of Montana State University near Moccasin, MT. The soil at this site is

93 classified as a Judith clay loam (fine-loamy, carbonatic, frigid Typic Calciustolls) with the water

94 holding capacity being limited by gravel content and a shallow soil profile $(60 \mathrm{~cm})$. Long term

95 (1909 - 2013) average crop growing season (September to August) precipitation in this area is

96 about $390 \mathrm{~mm}$ with mean air temperature of about $5.8^{\circ} \mathrm{C}$. In Table 1 the monthly precipitation

97 and average temperature during the study as well as the 20-yr long-term averages are presented.

98 The experiment was conducted from 2008 to 2011 in a land that was fallowed in the previous

99 year (2007). Experimental plots were laid out in a randomized complete block design with four

100 replicates. To avoid the confounding effect of varying weather conditions on crop rotation

101 effects, each phase of the crops was designed to appear in each rotation year. The details of

102 operation practices for each crop are shown in Table 2. 


\section{Energy balance}

Energy balance was evaluated using the process analysis methodology [8], accounting for energy used for manufacture and operation of farm machinery, fuel, lubricants, fertilizer, and pesticides. Inputs were converted to energy equivalents using standard coefficients (Table 3). Among the available coefficients, we selected the most up-to-date values that have been used for energy analysis in similar environments. The primary source of energy coefficients of machineries was Burgess et al. [5], which accounted for fuel and lubrication consumption as well as energy to manufacture machinery and amortized over its useful life. Energy coefficients for herbicides are derived from Krohn and Fripp [14]. Grain used as seed was not included as energy input; instead, it was subtracted from the harvested grain [13]. Neither environmental inputs (solar radiation, precipitation water, wind, nutrient dry and wet deposition, and so forth) nor labor inputs were considered in the energy input calculation since labor usually has an insignificant share in total energy inputs of the mechanized farming systems [33]. Energy costs for delivering the products to off-farm location, storage, and drying were not also considered. The total energy input (MJ ha' ${ }^{1}$ ) of each crop was calculated by summing all inputs used in the production procedure (Fig. 1). Energy input used in whole rotation was also calculated by summing the energy used for each crop in the rotation (Table 4).

Energy output was determined as a function of grain yield and grain higher heating values obtained from bomb calorimeter combustion $\left(18.5,18.2\right.$, and $26.5 \mathrm{MJ} \mathrm{kg}^{-1}$ for winter wheat, barley and camelina respectively). Crop residue did not get an allowance in energy analysis since they remained on the field and returned to the soil [33]. The energy balance of each cropping system was evaluated using two energy performance indicators as follow:

$$
\text { - Energy efficiency: Energy Output }\left(\mathrm{MJ} \mathrm{ha}^{-1}\right) / \text { Energy Input }\left(\mathrm{MJ} \mathrm{ha}^{-1}\right)
$$


129 In this paper, the term energy efficiency will be used in the common general sense of efficiency

130 (greater efficiency being desirable). We first focused on energy analysis of the cropping systems

131 based on the common practices done for each crop in the region. Thereafter, we evaluated the 132 possible options to improve energy balance of the systems.

\section{Data Analysis}

135 Data from the first year of the experiment (2008) was not included in the statistical analysis.

136 Data of energy output and energy balance indices were subject to ANOVA using PROC GLM of

137 SAS software. Fisher's least significant difference test (LSD) at $P<0.05$ was employed to 138 separate the means when F-test indicated significant differences.

\section{Results and discussion}

\section{Energy Input}

142 Comparing energy input used for the production of individual crops, winter wheat was the most 143 energy-demanding crop with $8284 \mathrm{MJ} \mathrm{ha}^{-1}$ non-renewable energy input requirement (Fig. 1).

144 This value of energy input is quite similar to the average energy input of $9053 \mathrm{MJ} \mathrm{ha}^{-1}$ reported 145 for winter wheat in the Canadian Prairies [33]. Barley and camelina were ranked following 146 winter wheat with the total energy input of 6156 and $5968 \mathrm{MJ} \mathrm{ha}^{-1}$. Energy input used in fallow 147 period was considerably lower $\left(898 \mathrm{MJ} \mathrm{ha}^{-1}\right)$ than those used for crop production. 
148 Very limited information exists in the literature regarding energy input of camelina. Petre et al.

149 [25] reported $31404 \mathrm{MJ} \mathrm{ha}^{-1}$ energy input for camelina in Romania which is considerably higher

150 than that used in the current study. The discrepancy between energy requirements for camelina in

151 these studies are due to differences in system boundaries and management practices, especially

152 high levels of chemical fertilizer, high rate of herbicide, and intensive soil preparation in Petre et

153 al., [25] work. Compared to similar biofuel crops such as canola, camelina in the condition of

154 current study had lower energy input. Fore et al. [9] reported $9506 \mathrm{MJ} \mathrm{ha}^{-1}$ and Smith et al. [30]

155 reported $7651 \mathrm{MJ} \mathrm{ha}^{-1}$ energy input requirement for canola production in Minnesota and western

156 Canada. For other biofuel crops such as soybean, energy input has been varied from 4588 [9] to

$15715506 \mathrm{MJ} \mathrm{ha}^{-1}[26]$.

158 The energy expenditure for fallow period in the current study is also lower than that (ranged

159 from 1332 to $1581 \mathrm{MJ} \mathrm{ha}^{-1}$ depending on the management practice) reported by Zentner et al.

160 [33] in the Canadian Prairies, which could be related to no till practices implemented in the

161 current study.

162 Except in the fallow period in which herbicide was the only energy consuming input, nitrogen

163 fertilizer was the most energy demanding input accounting for 76,68 and $69 \%$ of the total

164 energy input used in wheat, barley and camelina, respectively. Our results agreed with reports by

165 other researchers $[5,33]$ who reported a proportion of more than $70 \%$ o nitrogen in total energy

166 input of the cropping systems in the northern Great Plains as well as most previous studies in

167 other regions $[12,21,29]$. This is while the national U.S. average of nitrogen proportion in total

168 energy expenditure in winter wheat is about 47\% [27]. Higher share of nitrogen in the current

169 study is due to relatively low constitution of other inputs in this dryland farming system. 
170 Considering the total energy expenditure in the complete rotation, the lowest energy input was

171 used in the traditional WW-FAL (9182 $\mathrm{MJ} \mathrm{ha}^{-1}$ ) whereas 57 and 55\% more energy input was

172 invested in WW-BAR and WW-CAM compared to WW-FAL, respectively (Fig.1).

173

174 Energy Output

175 The energy output of individual crops, therefore the cropping systems varied considerably across 176 the years (Table 4). When comparing energy yield of winter wheat in different rotations, always 177 greater energy was obtained from wheat rotated with fallow. Lower grain yield thus energy 178 output of wheat in rotation with camelina and barley is attributed to lower content of stored water 179 in the soil which limited moisture availability for wheat in the intensified cropping systems 180 compared to that in WW-FAL rotation (for details see Chen et al. [6].

181 Camelina gross energy output in this study ranged from 31740 to $11690 \mathrm{MJ}^{-1}$ (Table 4). 182 Limmited data are available reporting energy output of camelina especially in dryland farming 183 systems. However, compared to irrigated canola [22, 31], energy output of camelina was lower 184 which was due to low grain yield harvested in this dryland system. As shown in table 4, camelina 185 energy yield was extremely low in 2011. Excessive rainfall received during May and June (when 186 camelina was blooming) adversely influenced camelina pollination and grain formation in this 187 year.

188 Total energy output of the cropping systems also varied across the experimental years (Table 4). 189 In 2009 and $2010 \mathrm{WW}-\mathrm{BAR}$ and WW-CAM rotations produced 49 and 44\% (averaged over two 190 years) greater gross energy output compared to WW-FAL. However, in 2011 due to a 191 considerably low yield of all crops, energy output of intensified cropping systems declined; no 192 significant differences were observed between cropping systems in this regard (Table 4). 
193 Averaged over three years of the experiment, the highest energy output was belonged to WW194 CAM rotation, though it was not significant with that of WW-BAR. Both of alternative rotations 195 produced significantly greater energy output than traditional WW-FAL rotation.

\section{Energy Indices}

198 Except in 2011, the lowest net energy was belonged to WW-FAL rotation (Table 4). Averaged 199 over three years, WW-CAM produced the greatest net energy which was 30 and 6\% greater than 200 that obtained from WW-FAL and WW-BAR rotations. Liska and Cassman [18] proposed net 201 energy as a standard metric for energy productivity of biofuel production systems. This indicator

202 can be suitably used to compare the different cropping systems in terms of energy productivity $203[12,22,29,33]$. In dryland farming systems crops performance is greatly influenced by the 204 environmental conditions, which can also impact the energy performance of the cropping 205 systems. In the present study and under favorable environmental conditions (like 2010) 206 intensified cropping systems yielded greater net energy than WW-FAL rotation. It shows that 207 higher energy invested in the alternative systems was completely offset by greater energy output 208 of these cropping systems.

209 Considering camelina net energy yield, net energy of $18283 \mathrm{MJ}^{-1}$ was obtained from this crop 210 (averaged over three years). As mentioned previously, one necessary criterion for a biofuel to be 211 a sustainable alternative to the petroleum fuels it displaces is a positive net energy balance [9]. 212 Camelina net energy yield in the current study is considerably greater than that reported for 213 generic biofuel crops such as soybean and canola [9], but lower than biomass crops [1, 3, 7, 16].

214 This clearly shows the potential of camelina as a biofueld feedstock as considerably less fossil 215 energy inputs in the production processes than the energy contained in the product. 
216 Energy efficiency of the cropping systems is shown in table 4. Values of energy efficiency of the

217 cropping systems were relatively high, especially in 2010, showing that non-renewable energy

218 sources were efficiently consumed in these cropping systems. No significant differences were

219 found between energy efficiency of the three rotations in 2009 and 2010 whereas WW-FAL

220 outperformed alternative rotations in 2011 (Table 3). According to Anova, no statistical

221 significant difference was found between energy efficiency of WW-FAL and WW-CAM rotation

222 averaged over three years of the experiment. Taking into account the greater net energy of WW-

223 CAM as well as similar efficiency in consumption of non-renewable energy, it can be concluded

224 that WW-CAM outperformed the traditional WW-FAL rotation in energetic perspective.

225

226 Potentials to improve energy efficiency

227 The sustainability of the alternative cropping systems could be further improved through 228 enhancing the energy efficiency, by either increasing energy output (yield) or reducing energy 229 inputs. The former can be achieved through the selection of high yielding cultivars. Recently, 230 several newly developed camelina cultivars have been tested and some of them have shown 231 considerable yield advantages over existing cultivars (Chen unpublished data). The later 232 (reducing energy input) can also be achieved through the optimization of the agronomic 233 practices. In the recent years, extensive research efforts have been made to determine the 234 optimum practices for different cropping systems in this area. Based on our experiences, the 235 following refinements can be recommended to reduce energy input in the studied cropping 236 systems without any unfavorable effects on the system productivity (crop yield):

237 For the fallow period, instead of $1.68 \mathrm{~L} \mathrm{ha}^{-1} 2,4-\mathrm{D}$ which is usually used in early to midsummer, $238 \quad 0.7 \mathrm{~L} \mathrm{ha}^{-1} 2$, 4-D can be used to reduce the total energy input of fallow period by $13.7 \%$. Also, 
239 instead of $90 \mathrm{~kg} \mathrm{~N} \mathrm{ha}^{-1}$ which is usually broadcast for winter wheat at late-tillering stage, a rate 240 of $67 \mathrm{~kg} \mathrm{~N} \mathrm{ha}^{-1}$ may be sufficient. These two adjustments in agronomic practices will lower total 241 energy input of wheat by $12.7 \%$. For barley following winter wheat also one extra application of 242 glyphosate in early spring $\left(1.12 \mathrm{~L} \mathrm{ha}^{-1}\right)$ is necessary. However, instead of broadcasting $52 \mathrm{~kg} \mathrm{~N}$ $243 \mathrm{ha}^{-1}$, application of $35 \mathrm{~kg} \mathrm{~N} \mathrm{ha}^{-1}$ may be sufficient. Therefore, $11.1 \%$ of energy will be saved for 244 barley production if these changes are applied in the production process. Among the crops we 245 evaluated in this study, energy efficiency of camelina has the biggest potential to be improved 246 through the optimization of management practices. Our previous experiments showed that the 247 application of starter fertilizer is not necessary for camelina after winter wheat as $\mathrm{N}, \mathrm{P}$ and $\mathrm{S}$ 248 carry over from the previous crop is sufficient for the crop requirements. The same amount of 249 nitrogen $\left(52 \mathrm{~kg} \mathrm{ha}^{-1}\right)$, however, is necessary to be broadcasted at rosette stage to meet the crop 250 demand. Also application of a grassy herbicide (Poast or any other herbicides) is not essential. 251 Through the optimization of fertilizer and herbicide consumption, almost $29 \%$ of total energy 252 input of camelina can be saved which in turn will greatly influence energy use efficiency in 253 CAM-WW rotation. For example, considering the actual yield of the current study and assuming 254 that the inputs are optimized, energy efficiency of CAM-WW rotation will raise from 4.6 to 5.8, 255 which is almost than $26 \%$ improvement.

\section{Conclusion}

258 According to the results of the present study, intensified cropping systems required more energy 259 input compared with the traditional FAL-WW rotation. The greater amount of energy expended 260 in the intensified cropping systems, however, was completely offset by more energy output of 261 the alternative system (e.g. CAM-WW). Net energy obtained from the intensified cropping 
262 systems was considerably greater than the control (depending on the environmental conditions)

263 whilst these systems did not differ in term of energy efficiency. It can be concluded that the

264 alternative cropping systems including the bio-energy crop (CAM-WW) outperformed

265 traditional FAL-WW system in energetic perspective. In all rotations, nitrogen fertilizer was the

266 most energy consuming input and accounted for nearly $70 \%$ of the total energy input used in this

267 dryland farming system. There is a big potential to improve the energy performance of the

268 alternative cropping systems, especially CAM-WW in this region. Refinement of management

269 practices will even more improve the sustainability of the alternative cropping systems in terms

270 of energy balance.

271

272

273 Compliance with Ethical Standards

274 We declare that:

275 - The data presented in this paper is original and have not been manipulated

$276 \quad-\quad$ The manuscript has not been submitted to more than one journal for simultaneous

277 consideration

$278 \quad-\quad$ The manuscript has not been published previously (partly or in full)

279 - Proper acknowledgements and citations to other works are given

280 - The manuscript has been approved by all the authors and consent to submit has been

281 received explicitly from all co-authors, as well as from the responsible authorities

282 - Authors whose names appear on the submission have contributed sufficiently to the

$283 \quad$ scientific work

284 - Chengci Chen, Reza Keshavarz-Afshar, and Karnis Neill declare that they have no

285 conflict of interest (financial or non-financial). 
- This study is supported by USDA Western Sustainable Research and Education grant, No. 080019002; Montana Agricultural Experiment Station; and USDA-NIFA BRDI grant, No. 2012-10006-20230.

- This article does not contain any studies with human or animal subjects.

\section{References}

1. Afshar RK, Chaichi MR, Alipour A, Ansari M, Dashtaki M, Hashemi M (2015) Potential of Milk Thistle for Biomass Production in Semi-Arid Regions. Crop Sci (Accepted)

2. Alluvione F, Moretti B, Sacco D, Grignani C (2011) EUE (energy use efficiency) of cropping systems for a sustainable agriculture. Energy 36: 4468-4481

3. Angelini LG, Ceccarini L, Di Nasso NN, Bonari E (2009) Long-term evaluation of biomass production and quality of two cardoon (Cynara cardunculus L.) cultivars for energy use. Biomass Bioenerg, 33: 810-816

4. Bailey AP, Basford WD, Penlington N, Park JR, Keatinge JDH, Rehman T, et al. (2003) A comparison of energy use in conventional and integrated arable farming systems in the UK. Agr Ecosyst Environ 97: 241-53

5. Burgess MH, Miller PR, Jones CA (2012) Pulse crops improve energy intensity and productivity of cereal production in Montana, USA. J Sustain Agr 36: 699-718

6. Chen C, Bekkerman A, Keshavarz Afshar R, Neill K (2015) Intensification of Dryland Cropping Systems for Bio-feedstock Production: Evaluation of Agronomic and Economic Benefits of Camelina sativa. Ind Crops Prod (accepted).

7. Cosentino SL, Copani V, D’Agosta GM, Sanzone E, Mantineo M (2005) First results on evaluation of Arundo donax L. clones collected in Southern Italy. Industrial Crops and Products 23: 212-22 
311 8. Fluck RC, Baird CD (1980) Agricultural energetics. Westport: CT: AVI.

312 9. Fore SR, Porter P, Lazarus W (2011) Net energy balance of small-scale on-farm biodiesel

313 production from canola and soybean. Biomass Bioenerg 35: 2234-2244

314 10. Gesch RW (2014). Influence of genotype and sowing date on camelina growth and yield in

315 the north central US. Ind Crop Prod 54: 209-215

316 11. Gugel RK, Falk KC (2006). Agronomic and seed quality evaluation of Camelina sativa in 317 western Canada. Can J Plant Sci 86: 1047-1058

318 12. Hülsbergen K, Feil B, Diepenbrock W (2002) Rates of nitrogen application required to 319 achieve maximum energy efficiency for various crops: Results of a long-term experiment. $320 \quad$ Field Crop Res 77: 61-76

321 13. Khakbazan M, Mohr, RM, Derksen, DA, Monreal, MA, Grant, CA, Zentner, RP, Moulin, 322 AP, McLaren, DL, et al. (2009) Effects of alternative management practices on the 323 economics, energy, and GHG emissions of a wheat-pea cropping system in the Canadian $324 \quad$ Prairies. Soil Till Res 104: 30-38

325 14. Krohn BJ, Fripp M (2012) A life cycle assessment of biodiesel derived from the "niche 326 filling” energy crop camelina in the USA. Appl Energ 92: 92-98

327 15. Lavigne A, Powers SE. (2007) Evaluating fuel ethanol feedstocks from energy policy 328 perspectives: a comparative energy assessment of corn and corn stover. Energ Policy 35: $329 \quad 5918-30$

330 16. Ledda L, Deligios PA, Farci R, Sulas L (2013) Biomass supply for energetic purposes from 331 some Cardueae species grown in Mediterranean farming systems. Ind Crop Prod 47: 218$332 \quad 226$ 
17. Lewandowski I, Schmidt U (2006) Nitrogen, energy and land use efficiencies of miscanthus, reed canary grass and triticale as determined by the boundary line approach. Agric Ecosyst Environ 112: 335-46

18. Liska AJ, Cassman KG (2008) Towards standardization of life-cycle metrics for biofuels: Greenhouse gas emissions mitigation and net energy yield. J Biobased Mater Bio 2: 187-203

19. Mandal KG, Hati KM, Misra AK (2009) Biomass yield and energy analysis of soybean production in relation to fertilizer-NPK and organic manure. Biomass Bioenerg 33: 16701679

20. McVay KA, Khan QA (2011) Camelina yield response to different plant populations under dryland conditions. Agron J 103: 1265-1269

21. McLaughlin NB, Hiba A, Wall GJ, King DJ (2000) Comparison of energy inputs for inorganic fertilizer and manure based corn production. Can Agr Eng 42: 9-18

22. Mousavi-Avval SH, Rafiee S, Jafari A, Mohammadi A, (2011) Improving energy use efficiency of canola production using data envelopment analysis (DEA) approach. Energy 36: $2765-2772$

23. Patzek TW (2004). Thermodynamics of the corn-ethanol biofuel cycle. Crit Rev Plant Sci 23:519-567.

24. Pervanchon F, Bockstaller C, Girardin P (2002) Assessment of energy use in arable farming systems by means of an agro-ecological indicator: the energy indicator. Agric Syst 72:14972

25. Petre SM, Jurcoane S, Dobre P, Petcu R, Dimitriu D (2012) Life cycle assessment: byproducts in biofuels production battle; rapeseed vs. Camelina sativa L. AgroLife Scientific Journal 2: 58-65 
26. Pimentel D, Patzek TW (2005) Ethanol production using corn, switchgrass and wood; biodiesel production using soybean and sunflower. Nat Resour Res14:65-76

27. Piringer G, Steinberg LJ (2006) Reevaluation of energy use in wheat production in the United States. Journal of Industrial Ecology 10: 149-167

28. Pradhan A, Shrestha DS, Van Gerpen J, Duffield J (2008) The energy balance of soybean oil biodiesel production: a review of past studies. Am Soc Agric Biol Eng 5:185-94

29. Rathke G, Diepenbrock W (2006) Energy balance of winter oilseed rape (Brassica napus L.) cropping as related to nitrogen supply and preceding crop. Eur J Agron 24: 35-44

30. Smith EG, Janzen HH, Newlands NK (2007) Energy balances of biodiesel production from soybean and canola in Canada. Can J Plant Sci 87: 793-801

31. Unakitan G, Hurma H, Yilmaz F (2010) An analysis of energy use efficiency of canola production in Turkey. Energy 35: 3623-3627

32. Vollmann J, Moritz T, Kargl C, Baumgartner S, Wagentristl H (2007) Agronomic evaluation of C. sativa genotypes selected for seed quality characteristics. Ind Crop Prod 26: 270-277

33. Zentner RP, Lafond, GP, Derksen, DA, Nagy, CN, Wall DD, May WE (2004) Effects of tillage method and crop rotation on non-renewable energy use efficiency for a thin Black Chernozem in the Canadian prairies. Soil Till Res 77: 125-136

\section{Acknowledgements:}

The authors like to thank Karnes Neill, Johnna Heser, and Kelly Arnold for technical support in the field and laboratory. The funding support of this project came from USDA Western Sustainable Research and Education grant, No. 080019002; Montana Agricultural Experiment Station; and USDA-NIFA BRDI grant, No. 2012-10006-20230. 
Table 1: Monthly precipitation and average air temperature during the study and long term average (LTA) at Moccasin, Montana.

\begin{tabular}{|c|c|c|c|c|c|c|c|c|c|c|c|}
\hline \multirow[t]{2}{*}{ Month } & \multicolumn{5}{|c|}{ Precipitation (mm) } & \multirow[t]{2}{*}{ Month } & \multicolumn{5}{|c|}{ Temperature $\left({ }^{\circ} \mathrm{C}\right)$} \\
\hline & 2008 & 2009 & 2010 & 2011 & LTA & & 2008 & 2009 & 2010 & 2011 & LTA \\
\hline Sep & 28.2 & 32.3 & 20.6 & 49.0 & 35.8 & Sep & 13.6 & 12.4 & 17.3 & 12.8 & 12.7 \\
\hline Oct & 23.6 & 19.1 & 73.9 & 11.2 & 23.1 & Oct & 8.7 & 9.2 & 1.8 & 10.6 & 7.2 \\
\hline Nov & 23.1 & 14.2 & 4.8 & 40.9 & 14.5 & Nov & 1.4 & 4.7 & 3.9 & -2.2 & 0.5 \\
\hline Dec & 0.5 & 8.9 & 8.6 & 17.0 & 13.7 & Dec & -3.3 & -8.8 & -9.1 & -3.3 & -3.9 \\
\hline Jan & 4.8 & 11.2 & 10.7 & 8.1 & 14.0 & Jan & -5.6 & -3.0 & -3.0 & -5.0 & -5.8 \\
\hline Feb & 5.3 & 5.1 & 5.1 & 15.0 & 11.4 & Feb & -1.9 & -1.5 & -1.5 & -8.3 & -4.1 \\
\hline Mar & 2.8 & 15.0 & 4.6 & 15.5 & 18.0 & Mar & 0.5 & -0.6 & 4.8 & -1.1 & -4.1 \\
\hline Apr & 11.2 & 36.6 & 27.9 & 59.9 & 30.5 & Apr & 2.8 & 4.2 & 5.3 & 3.3 & 5.0 \\
\hline May & 109.7 & 14.2 & 85.3 & 186.7 & 65.5 & May & 9.8 & 10.2 & 7.6 & 8.3 & 10.1 \\
\hline Jun & 74.7 & 23.9 & 66.3 & 107.4 & 79.5 & Jun & 13.6 & 13.7 & 13.6 & 13.3 & 14.3 \\
\hline Jul & 11.4 & 54.9 & 37.3 & 20.8 & 42.4 & Jul & 19.3 & 18.6 & 17.6 & 19.4 & 18.8 \\
\hline Aug & 22.6 & 39.6 & 96.0 & 18.0 & 41.7 & Aug & 19.4 & 18.3 & 18.1 & 20.0 & 18.3 \\
\hline Total & 317.9 & 275.0 & 441.1 & 549.5 & 390.1 & AVG. & 6.5 & 6.5 & 6.4 & 5.7 & 5.8 \\
\hline
\end{tabular}


Table 2: Details of agronomic practices used for each crop

\begin{tabular}{|c|c|c|c|}
\hline & Weed management & Fertilization & Planting and harvesting details \\
\hline Fallow & $\begin{array}{l}1.12 \mathrm{~L} \mathrm{ha}^{-1} \text { of glyphosate } \\
\text { in the fall. } \\
1.12 \mathrm{~L} \mathrm{ha}^{-1} \text { glyphosate in } \\
\text { the early spring. } \\
1.12 \mathrm{~L} \mathrm{ha}^{-1} \text { of glyphosate } \\
\text { plus } 1.68 \mathrm{~L} \mathrm{ha}^{-1} 2,4-\mathrm{D}^{\mathrm{b}} \\
\text { in early to midsummer. }\end{array}$ & & \\
\hline $\begin{array}{l}\text { Winter wheat } \\
\text { (cv. Yellowstone) }\end{array}$ & $\begin{array}{l}1.12 \mathrm{~L} \mathrm{ha}^{-1} \text { of glyphosate } \\
\text { in early September. } \\
1.68 \mathrm{~L} \mathrm{ha}^{-1} \text { bronate } \\
\text { (broadleaf herbicide). }\end{array}$ & $\begin{array}{l}112 \mathrm{~kg} \mathrm{ha}^{-1} \text { starter } \\
\text { fertilizer N-P } \mathrm{P}_{5}-\mathrm{K}_{2} \mathrm{O}- \\
\mathrm{S}(20-20-20-10) \text {. } \\
90 \mathrm{~kg} \mathrm{~N} \mathrm{ha}^{-1} \text { at late- } \\
\text { tillering stage. }\end{array}$ & $\begin{array}{l}\text { Direct-seeded with a } \\
\text { ConservaPak no-till air-seeder } \\
\text { at the rate of } 67 \mathrm{~kg}^{\mathrm{e}} \text { seed } \mathrm{ha}^{-1} \text {. } \\
\text { Harvested using a } \\
\text { Wintersteiger plot combine }{ }^{\mathrm{f}} \text { at } \\
\text { late July to early August. }\end{array}$ \\
\hline $\begin{array}{l}\text { Barley } \\
\text { (cv. Haxbey) }\end{array}$ & $\begin{array}{l}1.12 \mathrm{~L} \mathrm{ha}^{-1} \text { of glyphosate } \\
\text { in early September. } \\
1.68 \mathrm{~L} \mathrm{ha}^{-1} \text { bronate. }\end{array}$ & $\begin{array}{l}112 \mathrm{~kg} \mathrm{ha}^{-1} \text { starter } \\
\text { fertilizer N-P } \mathrm{P}_{2} \mathrm{O}_{5}-\mathrm{K}_{2} \mathrm{O}- \\
\mathrm{S}(20-20-20-10) \\
52 \mathrm{~kg} \mathrm{~N} \mathrm{ha}^{-1} \text { at late- } \\
\text { tillering stage. }\end{array}$ & $\begin{array}{l}\text { Direct seeded using a } \\
\text { ConservaPak no-till air-seeder } \\
\text { at a seeding rate of } 76 \mathrm{~kg} \mathrm{ha}^{-1} \text {. } \\
\text { Harvested in late July using a } \\
\text { Wintersteiger plot combine. }\end{array}$ \\
\hline $\begin{array}{l}\text { Camelina } \\
\text { (cv. Blaine } \\
\text { Creek) }\end{array}$ & $\begin{array}{l}1.12 \mathrm{~L} \mathrm{ha}^{-1} \text { of glyphosate } \\
\text { in the early September. } \\
1.12 \mathrm{~L} \mathrm{ha}^{-1} \text { of glyphosate } \\
\text { in prior to planting. } \\
1.12 \mathrm{~L} \mathrm{ha}^{-1} \text { Poast }^{\mathrm{d}} \text { (a } \\
\text { grassy herbicide) at late } \\
\text { rosette stage. }\end{array}$ & $\begin{array}{l}112 \mathrm{~kg} \mathrm{ha}^{-1} \text { starter } \\
\text { fertilizer N-} \mathrm{P}_{2} \mathrm{O}_{5}-\mathrm{K}_{2} \mathrm{O}- \\
\mathrm{S}(20-20-20-10) \text {. } \\
50 \mathrm{~kg} \mathrm{~N} \mathrm{ha}^{-1} \text { was in the } \\
\text { spring at rosette stage. }\end{array}$ & $\begin{array}{l}\text { Direct seeded (late March to } \\
\text { early April) using a } \\
\text { ConservaPak no-till air-seeder } \\
\text { at a seeding rate of } 5.6 \mathrm{~kg} \mathrm{~h}^{-1} \text {. } \\
\text { Harvested in early to mid-July } \\
\text { using a Wintersteiger plot } \\
\text { combine. }\end{array}$ \\
\hline
\end{tabular}

${ }^{\mathrm{a}} \mathrm{N}$-[phosphonomethyl] glycine

${ }^{\mathrm{b}}$ 2,4-dichlorophenoxyacetic acid

${ }^{\mathrm{c}}$ Bromoxynil

d 2-[1-(Ethoxyimino)butyl]-5-[2-(ethylthio)propyl]-3-hydroxy-2-cycloxexen-1-one

${ }^{\mathrm{e}}$ ConservaPak, Indian Head, SK, Canada

${ }^{\mathrm{f}}$ Wintersteiger Inc., Salt Lake City, UT 
Table 3: Energy coefficients used to convert inputs to their energy equivalents

\begin{tabular}{lcc}
\hline Input & $\begin{array}{c}\text { Energy coefficient } \\
\text { (MJ/input) }\end{array}$ & Reference \\
\hline Herbicides (L a.i.) & 274.63 & Krohn and Fripp [14] \\
Fertilizer (kg) & & \\
$\quad$ N & 56.7 & Burges et al. [5] \\
P2O5 & 9.5 & Burges et al. [5] \\
K2O & 9.9 & Burges et al. [5] \\
S & 1.12 & Zenter et al. [5] \\
Machinery (ha) & & \\
$\quad$ Air Seeder & 408 & Burges et al. [5] \\
$\quad$ Sprayer & 126 & Burges et al. [5] \\
$\quad$ Granular applicator & 91 & Burges et al. [5] \\
$\quad$ Combine & 350 & Burges et al. [5] \\
\hline
\end{tabular}

${ }^{a}$ Including energy for manufacturing, operating, maintenance, fuel and lubrication. 
Table 4: Energy balance indicators (means \pm standard errors) for two-year crop rotations in a dryland farming system of Central Montana.

\begin{tabular}{ccccc}
\hline Cropping system & $\mathbf{2 0 0 9}$ & $\mathbf{2 0 1 0}$ & $\mathbf{2 0 1 1}$ & Average \\
WW-FAL & \multicolumn{3}{c}{ Gross Output Energy $\left(\mathrm{MJ} \mathrm{ha}^{-1}\right)$} \\
Wheat & $43042( \pm 1681) \mathrm{b}$ & $60211( \pm 3510) \mathrm{b}$ & $46775( \pm 3924) \mathrm{a}$ & $50009( \pm 2556) \mathrm{b}$ \\
Fallow & 43042 & 60211 & 46775 & 50009 \\
WW-BAR & 0 & 0 & 0 & 0 \\
Wheat & $66075( \pm 3568) \mathrm{a}$ & $87654( \pm 1063) \mathrm{a}$ & $40544( \pm 3500) \mathrm{a}$ & $64758( \pm 2080) \mathrm{a}$ \\
Barley & 29047 & 49941 & 20618 & 33202 \\
WW-CAM & 37027 & 37712 & 19927 & 31555 \\
Wheat & $61066( \pm 3654) \mathrm{a}$ & $89001( \pm 6572) \mathrm{a}$ & $51778( \pm 3399) \mathrm{a}$ & $67282( \pm 3014) \mathrm{a}$ \\
Camelina & 32429 & 57261 & 40087 & 43259 \\
& 28637 & 31740 & 11690 & 24022
\end{tabular}

\begin{tabular}{ccccc}
\multicolumn{5}{c}{ Net Output Energy $\left(\mathrm{MJ} \mathrm{ha}^{-1}\right)$} \\
WW-FAL & $33860( \pm 1681) \mathrm{b}$ & $51029( \pm 3510) \mathrm{b}$ & $37593( \pm 3924) \mathrm{a}$ & $40827( \pm 2556) \mathrm{b}$ \\
Wheat & 34758 & 51927 & 38491 & 41725 \\
Fallow & -898 & -898 & -898 & -898 \\
WW-BAR & $51639( \pm 3568) \mathrm{a}$ & $73218( \pm 1063) \mathrm{a}$ & $26108( \pm 3500) \mathrm{a}$ & $50322( \pm 2080) \mathrm{ab}$ \\
Wheat & 20763 & 41657 & 12334 & 24918 \\
Barley & 30875 & 31560 & 13775 & 25403 \\
WW-CAM & $47042( \pm 3654) \mathrm{a}$ & $74977( \pm 6572) \mathrm{a}$ & $37754( \pm 3399) \mathrm{a}$ & $53258( \pm 3014) \mathrm{a}$ \\
Wheat & 24145 & 48977 & 31803 & 34975 \\
Camelina & 22898 & 26000 & 5951 & 18283 \\
& & & & \\
& & & & \\
WW-FAL & $4.7( \pm 0.19) \mathrm{a}$ & $6.6( \pm 0.38) \mathrm{a}$ & $5.1( \pm 0.43) \mathrm{a}$ & $5.4( \pm 0.28) \mathrm{a}$ \\
Wheat & 5.2 & 7.3 & 5.6 & 6.0 \\
Fallow & - & - & - & - \\
WW-BAR & $4.6( \pm 0.25) \mathrm{a}$ & $6.1( \pm 0.07) \mathrm{a}$ & $2.8( \pm 0.24) \mathrm{b}$ & $4.5( \pm 0.14) \mathrm{b}$ \\
Wheat & 3.5 & 6.0 & 2.5 & 4.0 \\
Barley & 6.0 & 6.1 & 3.2 & 5.1 \\
WW-CAM & $3.9( \pm 0.42) \mathrm{a}$ & $6.4( \pm 0.47) \mathrm{a}$ & $3.7( \pm 0.24) \mathrm{b}$ & $4.6( \pm 0.22) \mathrm{ab}$ \\
Wheat & 3.9 & 6.9 & 4.8 & 5.2 \\
Camelina & 5.0 & 5.5 & 2.0 & 4.2 \\
\hline
\end{tabular}

Mean were separated using LSD test at $\mathrm{P}<0.05$ (only energy indicators of cropping systems were compared not each individual crop). Means within a column with a common letter are not statistically different. 
400 Figure Caption:

401 Fig. 1: Energy input used for each crop (above) and total energy input used for each cropping 402 systems (below).

403

404 